\title{
Grundtvigs forhold til Luther og den lutherske tradition
}

\author{
Af Leif Grane
}

At beskæftige sig med Grundtvigs forhold til Luther og den lutherske tradition er det samme som at følge ham på hans vej fra begyndelsen til enden. Der findes ikke noget længere forl $\varnothing b$ under Grundtvigs lange livsvandring, hvor dette forhold ikke var væsentligt. Det er ikke så underligt, for det vil være svært at findé en teolog, der i højere grad end Grundtvig levede med hele den kristne tradition som sin selvfølgelige baggrund, og det måtte derfor være aldeles afgørende for ham at forstå og forholde sig til den del af traditionen, som havde rådet på vore egne breddegrader i de senere århundreder. Den nøgleposition, Grundtvig tildelte Luther i forbindelse med sin religiøse krise 181011, lod han reformatoren beholde til det sidste - trods de meget væsentlige nuanceringer, hans historie- og kristendomssyn undergik undervejs.

Det betyder derfor ikke, at synet på Luther og på den måde, arven efter ham blev forvaltet, forblev uforandret. Grundtvig holdt til sine dages ende fast ved Luthers enestående betydning, men de indsigter, han vandt undervejs, øgede kritikken - af Luther og især af hans efterfølgere.

Kildematerialet til en nærmere belysning af vort emne er for stort til at blive fyldestgørende behandlet eller blot omtalt i et enkelt foredrag. For en ordens skyld vil jeg dog lige nævne nogle af de vigtigste værker. Der er først de historiske fremstillinger: Verdenskrønikerne 1812 og 1817, Haandbog i Verdens-Historien, Christenhedens Syvstjerne og Kirke-Spejl, hvortil kommer en række digte og sange gennem årene. Skønt sondringen kun har betinget berettigelse, må hertil føjes nogle »teologiske « arbejder. Luther og den lutherske tradition er direkte eller indirekte på dagsordenen næsten hver gang, Grundtvig henvender sig til kristne, men hovedværkerne i så henseende er vel nok: Kirkens Gienmæle, Om den sande Christendom, Om Christendommens Sandhed, Skal den lutherske Reformation virkelig fortsættes?, Kirkelige Oplysninger især for lutherske Kristne, og Den kristelige Børnelærdom. Særdeles interessante er dog også de koncepter til årlige taler i Vartov om Luther, som C.J. Brandt har udgivet $\mathrm{i} »$ Kirkelige Lejlighedstaler«. 
Hvad skal vi nu stille op med dette vældige stof, der mageligt kan forøges yderligere? Lad mig betone, at det er Grundtvigs forhold til Luther og lutherdommen, dette drejer sig om. Spørgsmålet er ikke, hvordan Grundtvig tager sig ud, hvis man sammenligner ham med den moderne Lutherforsknings billede af Luther, men hvordan han tager sig ud, når han tager stilling til Luther og den lutherske tradition på sine egne betingelser. En sammenligning af lærepunkter uden hensyn til de 300 år, der er imellem dem, ville være uhistorisk og dermed uden interesse. En sådan fremgangsmåde ville $\mathrm{i} \phi \mathrm{vrigt}$ være fremmed for dem begge. Men skønt en sammenligning, der ikke inddrager deres af gode grunde vidt forskellige vilkår - et forhold, som for Grundtvig er en klar forudsætning for enhver stillingtagen til Luther - ville være meningsløs, er det naturligvis ikke urimeligt at inddrage forskelle, der umiddelbart giver sig af Grundtvigs måde at betragte Luther på.

Efter disse, alt for korte, indledende bemærkninger kan vi begynde med at konstatere, at forud for Grundtvigs livslange beskæftigelse med det lutherske gik en afvisning af det i den form, hvori han havde kendt det fra sin barndom. Det er almindeligt at sige, at faderen, Johan Grundtvig, var luthersk-ortodoks, hvad Grundtvig da også selv synes at bekræfte. Men hvad vil det sige? Vor konkrete viden om Faderens livsgrundlag er ret spinkel ${ }^{1}$. Der er grund til at antage, at faderens »ortodoksi« bestod $\mathrm{i}$ en tilslutning til den konservative supranaturalisme, hvis vigtigste repræsentanter hen mod slutningen af det 18. århundrede var biskop Balle og Ove Høegh Guldberg, hvis lærebog anvendtes i latinskolerne - altså det, Grundtvig i et tilbageblik over sit liv fra 1804 kalder »hele det fornuftknusende Apparat $\aleph^{2}$. Hvad bestod det i? Meget kort sagt var det bygget op på følgende måde: Først kom den naturlige teologi. Den fulgtes af en bevisførelse for Den hellige Skrifts troværdighed. Når det var overstået, kunne man ved den ufejlbare Bibels hjælp hente alle de klassiske lærepunkter i dogmatikken frem som basis for læren om dyder og pligter, hvis vigtighed man var helt enig med den mere radikale oplysningsteologi og den egentlige rationalisme om.

Grundtvig hævder selv, at det var læsningen af T.C. Bruuns »Skriftemaalet «, der gjorde en ende på ortodoksien for ham. Et par dagbogsnotater fra 1804 tyder virkelig på, at hans religion var reduceret til et minimum: Gud, dyd og udødelighed. Ikke desto mindre prædikede han nogle gange $\mathrm{i}$ studietiden og senere $\mathrm{i}$ sin 
Faders kirker. De korte indholdsangivelser, han bringer i dagbogen, viser, at prædikenerne var ren moralisme: de handlede om dyder og laster. Alligevel blev han præmieret med pengegaver af forældrene, som vel derfor ikke kan have fundet dem anstødelige. Det passer med tidsånden, hvis den såkaldt »luthersk-ortodokse « Fader har kunnet acceptere sådanne prædikener ${ }^{3}$.

Uanset om Grundtvig selv har forstået det - og det har han måske ikke - var hans »farvel « til det 18. århundredes »lutherskhed « definitiv. Den vendte han aldrig tilbage til. Selv vurderede han virkningen af T.C. Bruun-lekturen positivt: den befriede ham for fordomme $^{4}$. Man kunne også sige: grunden blev ryddet. Bruun hjalp ham af med »det fornuftknusende Apparat « - og efterlod ham i et kristeligt vakuum. Når han sidenhen forblev skeptisk over for teologers trang til at ordne tilværelsen ved hjælp af begrebsopstillinger, har det næppe noget med Bruun at gøre. Det skyldes hans historiesyn: det er kun erfaringen - herunder den kollektive erfaring, som historien udg $\varnothing \mathrm{r}$ - der kan lære os, hvad mennesket, og hvad kristendommen er.

Grundtvig kom til Egeløkke i 1805 med forsynstroen og moralismen i behold, men ikke mere. Det er interessant at konstatere, at den intensive læsning, der i forbindelse med forelskelsen giver ham et nyt syn på poesien og på historien som universalhistorie, åbenbart ikke umiddelbart forlener ham med et nyt sprog, når han skal prædike. Men med afhandlingen »Om Religion og Liturgie« finder den evighedslængsel, der var vakt hos ham, et første udtryk i sammenhæng med den kristne symbolik. Grundtvig selv betragtede det romantiske historiesyn, han fandt hos Schelling og Steffens, som et nødvendigt trin på sin vej fra den moralistiske fornuftreligion tilbage til kristendommen. "Asarusen« og beskæftigelsen med verdenshistorien i de følgende år er kun en bekræftelse på dette synspunkt, skønt det først var den religiøse krise 1810-11, der for alvor bragte ham videre. Dermed blev Luther væsentlig for aldrig mere at glide i baggrunden.

Spørgsmålet er nu, hvad det vil sige? I et forsøg på at besvare spørgsmålet vil jeg først overveje, hvad det var for en Luther, Grundtvig nu opdagede og tog med sig i de følgende års kamp. For det andet vil jeg i overblik prøve at skildre den forandring i Grundtvigs forhold til Luther, der sker efter den såkaldte »mageløse « opdagelse 1825, og for det tredje vil jeg diskutere nogle centrale spørgsmål i forbindelse med Grundtvigs forståelse af Luther og den lutherske tradition. 
Skønt de tanker om de syv menighedsbreve i Johannes' åbenbaring som nøgle til forståelse af kirkehistorien, som vi finder i et manuskript fra efteråret 1810 , først sent - og i ændret skikkelse - finder anvendelse, har åbenbart følgende ord i brevet til menigheden i Sardes (Apok. 3,1-2) brændt sig ind i Grundtvigs sind som et klart udtryk for situationen i den lutherske menighed: »Jeg kender dine gerninger, at du har ord for at leve og er dog død. Bliv vågen og styrk det, der er tilbage, men som var ved at $d \varnothing \ll$. Både i indledningsdigtet til Faderen i »Nytaarsnat eller Blik paa Kristendom og Historie« fra december 1810 og i digtet »Frants Volkmar Reinhards Minde« fra 1812 har Grundtvig disse ord i tankerne ${ }^{5}$. Begge steder er der tale om, hvordan tidens mænd i jubel tramper på Luthers grav. Fjernt fra forløber-tanken i manuskriptet om menighedsbrevene er det heller ikke, når Grundtvig $\mathrm{i}$ det sidstnævnte digt udbryder: "Ja, le kun frit, jeg veed du vil,/ du Mørkets rædde Skare!/ Kald mig i Spot kun Luther-lil,/ jeg skal til Navnet svare«. Med beslutningen om at kæmpe for kristendommen, både mod rationalisterne og mod tilhængerne af den nye filosofi, tog Grundtvig helt utilsløret Luther som forbillede. "Styrk det, der er tilbage, men som var ved at $\mathrm{d} \varnothing$ «, det var ord, der for Grundtvig talte lige ind i den situation, han befandt sig $\mathrm{i}$.

Manuskriptet om menighedsbrevene er ikke dateret, men henvisningen - af William Michelsen - til efteråret 1810 er uden tvivl korrekt ${ }^{6}$. Placeringen af ham selv som forløber for den 6. reformator svarer til det »sværmeri«, som han selv kaldte det, der gik forud for krisen ${ }^{7}$. Men også en anden ting viser, at dateringen er rigtig. Luther bliver nemlig kritiseret for at overdrive med hensyn til gode gerninger, dvs. for at fraskrive dem betydning for saligheden ${ }^{8}$. Der er intet påfaldende $\mathrm{i}$, at Luther kritiseres. Det var han for Grundtvig på intet tidspunkt hævet over. Men kritikkens indhold viser klart, at vi befinder os $\mathrm{i}$ tiden inden krisen. Først læsningen af Bibelen og af Luthers og Kingos salmer bragte $\mathrm{i}$ forening med sammenbruddet Grundtvig ud over den sidste rest af moralismen'.

Lejlighed til at udfolde sin forståelse af Luthers værk fik Grundtvig, da han i 1812 udgav sin første verdenskrønike. Læser man afsnittet om reformationen, bliver det ganske klart, hvori han så Luthers indsats. Han fremhæver, at Luther forkastede alt, "som ei var grundet paa tydelige Ord i de hellige Skrifter - som Løgn og Vildfarelse«, og at han udlagde Bibelen på tysk. »Den synderligste Deel 
og ligesom Hovedet af hans Lære, var, at Mennesket formeedelst Adams Synd var blevet uduelig til at opfylde Loven, som befaler at elske Gud over alle Ting og Næsten som sig selv, men at Kristus havde opfyldt den i vort Sted, og baaret Syndens fortjente Straf; at ham er givet al Magt baade i Himlen og paa Jorden, og at han er vor eneste Talsmand hos Faderen ${ }^{10}$. Bibelen, »Guds skrevne Ord «, som Grundtvig andetsteds kalder den, er sandheden om menneskets vilkår og derfor også den prøvesten, der skal skelne mellem sandhed og løgn. I den anførte korte sammenfatning af Luthers lære er hele den bibelske historie indregnet: skabelse, syndefald, forløsning og fuldendelse. Det er altså det centrale indhold af Bibelen, det drejer sig om. Heller ikke i sin bibeltroende periode opfatter Grundtvig Bibelen som det, man har kaldt en »formalautoritet «. Han er ganske vist overbevist om, at alt i Bibelen er bogstavelig sandhed, og lejlighedsvis kan han udtrykke sig meget håndfast, men hans interesse samler sig om det, han forstår ved det bibelske historiesyn, der har Kristus til centrum, hvad allerede Steffens havde lært ham. Da han så tidligt som i »Om Religion og Liturgie« var klar over - hvad han fastholdt resten af livet - at al religion må og skal forstås historisk ${ }^{11}$, ligger en luthersk-ortodoks anvendelse af Bibelen som opslagsbog med henblik på konstruktion af et dogmatisk system ham også i denne periode aldeles fjernt. Udtrykket "prøvesten« om Bibelen svarer ganske godt til den måde, hvorpå Luther gør Bibelen til kriterium for teologisk bevisførelse ${ }^{12}$. For dem begge forudsætter en sådan Bibelbrug troen på kristendommens budskab, der - ligeledes for dem begge - er enfoldigt og enkelt.

Det er altså min påstand, at den Luther, Grundtvig nu har sluttet sig til og gjort til sit forbillede i kampen mod tidens vantro, ikke har megen lighed med luthersk ortodoksi i traditionel forstand. Efter min mening kommer man ingen vegne ved at bruge clicheer som »luthersk bibeltroende«. Hvor meget end Grundtvig i denne periode kan udtrykke sig, som om han havde skrævet hen over den nu af ham forkastede naturfilosofi og den heftigt bekæmpede oplysningsteologi for at nå tilbage til ortodoksiens bibeltro, kunne det aldrig lykkes ham. Årene siden hans romantiske opvågnen i 1805-06 havde efterladt dybe spor, som intet opgør med Schelling som det, han foretog både $\mathrm{i}$ Verdenskrøniken 1812 og i de følgende år, kunne udslette. Uden at alt det, Grundtvig havde tilegnet sig de foregående år, forsvinder af hans bevidsthed, er Luther nu blevet symbolet på det 
bibelske historiesyn. Hans såkaldte »lutherske ortodoksi« er hans ejendommelige prægning af den nye forståelse af historien, som var brudt igennem med romantikken, $o g$ den forståelse af reformationen, som han tager som udgangspunkt for sin kamp mod tidens vantro.

Den lutherske ortodoksi $\mathrm{i}$ historisk forstand tager han allerede $\mathrm{i}$ 1812 afstand fra, ja, han går endnu længere, idet han noterer sig Melanchthons afvigelser fra Luther, især med hensyn til de gode gerninger og nadveren, og i $\emptyset$ vrigt betragter de interne lutherske stridigheder $\mathrm{i}$ sidste del af det 16 . århundrede som begyndelsen til den forkrøbling af lutherdommen, som ortodoksien for ham repræsenterer $^{13}$. Verdenskrøniken 1817 ligger på samme linie, for en stor del med de samme ord, men kritikken af ortodoksien er her endnu skarpere. Allerede her vender Grundtvig sig imod, at man tillagde de symbolske bøger en autoritet, der svarede til pavens ${ }^{14}$. Så længe Luther levede, gik det godt - det er det gentagne omkvæd på hans vurdering af lutherdommens historie, der i øvrigt er kendetegnet af en accelererende forvrængning. Når man betænker, hvorledes Grundtvig betragtede kirkens situation på sin egen tid, er det ikke underligt, at senmiddelalderens kirkelige tilstand synes at svare til, hvad der er sket fra Luther til Grundtvigs egen tid. ${ }^{15}$ Det er derfor også klart, at det er Luther, ikke lutherdommen, der må være hans forbillede.

Hvad læren angik, fandt Grundtvig, at Confessio Augustana præcist udtrykte Luthers og Melanchthons fællesskab, inden den sidste efter Luthers død gik sine egne veje ${ }^{16}$. De andre reformatorer, Zwingli og Calvin, får en mindre smigrende omtale. De manglede Luthers poetiske sans og profetiske forkyndelse, og de fejlede i nadverlæren ${ }^{17}$. Grundtvig havde i »Om Religion og Liturgie« 180607 selv hyldet en nærmest zwinglisk nadverlære ${ }^{18}$, men nu - og i al fremtid - tager han afstand fra såvel Zwingli som Calvin og holder sig til Luther. Det er blevet diskuteret, om han nu også virkelig følger Luther i synet på nadveren, et kompliceret spørgsmål, som naturligvis kræver en indgående undersøgelse af Luthers nadverlære, der i sig selv er genstand for diskussion ${ }^{19}$. Det må jeg lade ligge $i$ denne sammenhæng. Det står i hvert fald fast, at Grundtvig i alle faser af sit forfatterskab vender sig heftigt mod såvel den romerskkatolske forvandlingslære som mod Zwinglis og Calvins nadverforståelser.

Grundtvigs skildring af reformationen og det billede af Luther, han tegner i verdenskrønikerne og i øvrigt går ud fra i sin kamp mod 
samtidens teologi, må ud fra datidens muligheder siges at være vellykket. Han kan da også i 1830 helt vedkende sig, hvad han har skrevet i 1812 og $1817^{20}$. Luthers Kristusforkyndelse i sammenhæng med synd og nåde, lov og evangelium, er indholdet, bygget på Bibelen. Luthersk og bibelsk kristendom er indtil 1825 for Grundtvig ét og det samme. Det var Luthers bedrift at have oversat Bibelen til tysk og udlagt den for folket på dets modersmål.

Denne forståelse af reformationen og af Luther som dens sande talsmand fastholdt Grundtvig til sine dages ende, men den sammenhæng, Lutherforståelsen indgik i, ændrede karakter i takt med hans historie- og menneskesyn, hvorved også vurderingen forandrede sig. Det mærkes naturligvis særligt tydeligt fra 1825 , men vil formentlig også kunne påvises især $\mathrm{i}$ de sidste år forinden, da han atter var blevet præst, og omridsene af et kirkesyn begynder at melde sig. Måske kan man sige, at to tendenser, der ikke umiddelbart synes at harmonere med hinanden, gør sig gældende. På den ene side leder tanken om menigheden som gudsfolket, samlet om troen og dåben, $\mathrm{i}$ økumenisk retning, samtidig med at Grundtvig på den anden side, ved igen at stå over for den kirkelige rationalisme, griber til at betone den lutherske bekendelse som forsvar mod kristentroens udvanding og forvrængning.

Dermed befinder vi os på det tidspunkt, da Grundtvig med »Kirkens Gjenmæle« formulerede sin kirkeforståelse. Jeg er klar over utilstrækkeligheden $\mathrm{i}$ det hidtil sagte, som dog et foredrags begrænsede muligheder må tage noget af skylden for, og vil nu gå over til tiden efter 1825. Da Grundtvig med »Kirkens Gjenmæle« lod Kristi ord til menigheden ved dåb og nadver, sammen med Fader vor og lovsangen, overtage den plads, han hidtil havde givet »Guds skrevne Ord «, måtte det få indflydelse på vurderingen af Luther. I første omgang mærkes det dog kun lidt. Såvel den indledende citering af Den augsburgske Bekendelse, artikel 7, som den udtrykkelige henvisning til Luther i selve skriftet, med betoning af, at reformatorerne med Luther som hovedmand nok som teologer havde hævdet Skriften som trosregel over for papisterne, men at de som præster altid forudsatte kirken og troen, skal vise, at han fortsat står på luthersk grund. Men det skal også understrege, at det, Grundtvig har opdaget, har været der hele tiden, takket være Luthers lille katekismus. Samtidig er dog grunden lagt til en kritik af Luther og reformationen af en art, som ikke hidtidig havde været mulig. Den kritik af Luther, 
vi møder i verdenskrønikerne og andetsteds i årene før 1825 , gik alene på svagheder ved Luthers person, men fra nu af, kan man sige, er kritikken saglig, mens Luthers personlige mangler nærmest omtales for at undskylde ham.

I de to store afhandlinger, »Om den sande Christendom « og »Om Christendommens Sandhed «, som Grundtvig skrev i umiddelbar forlængelse af »Kirkens Gjenmæle«, søgte han teologisk at begrunde sit kirkesyn. Ved læsningen kan man iagttage, hvordan han efterhånden kommer til klarhed over konsekvenserne af sin nye indsigt. Til at begynde med er han meget ivrig efter at vise, at Ny Testamente og Luther er på hans side. Han vidste naturligvis godt, at han havde brudt med det såkaldte protestantiske »skriftprincip« - det er han i $\emptyset$ vrigt allerede $\mathrm{i}$ »Kirkens Gienmæle« klar over - men i den første af de to afhandlinger sættes der lighedstegn mellem bibelsk, luthersk og sand kristendom, idet Grundtvig igen benytter Den augsburgske Bekendelse som repræsentativ for lutherdommen. Først $\mathrm{i} » \mathrm{Om}$ Christendommens Sandhed « rettes kritikken for alvor mod reformationen selv og ikke blot mod dens efterfølgere. Han gør grundigt op med det protestantiske skriftprincip og får i sidste dels sondring mellem skrift og mundtligt ord fuld klarhed over sin uenighed med Luther.

Det er dog først afhandlingerne om religionsfrihed fra 1827, der skaber grundlaget for de klare sondringer mellem kirke og stat og mellem kirke og skole, som udfoldes 1830 i "Skal den lutherske Reformation virkelig fortsættes? « Dermed er de væsentlige positioner nået, skønt meget nyt føjes til i senere værker. Håndbog i verdenshistorie III rummer således i udkast den forståelse af kirkehistorien og af Luthers placering i den, som siden udformes nærmere, dels $\mathrm{i}$ poetisk form i »Christenhedens Syvstjerne«, dels i foredrag i »KirkeSpejl«. En første sammenfatning heraf foreligger i øvrigt i den meget spændende artikel »Om Kirkehistorien « fra 1847. På linie hermed er »Kirkelige Oplysninger, især for lutherske Kristne«, medens. »Den christelige Børnelærdom« under påvirkning af Søren Kierkegaards kamp skærper polemikken mod den lutherske tradition.

Det nye kirkesyn måtte medføre en afvisning af enhver luthersk konfessionalisme. Dåbens og troens ægthed afhang jo af deres apostolske oprindelse, ja, af deres udspring hos Kristus selv. Følgelig kunne intet almengyldigt i kirken være opstået i det 16. århundrede. Grundtvigs syn på Luther og lutherdommen må derfor fremtidig bero på, hvor langt det lutherske er alment kristeligt, dvs. svarer til det, 
som alle kristne er fælles om. Han kunne ikke længere være partisk for reformationen, især den evangelisk-lutherske, som han siger i sit litterære testamente fra $1827^{21}$. Det fik ham imidlertid ikke til at vende sig mod Luther. Han kunne stadig forstå, og også forsvare, at Luther i kampen mod pavedømmet holdt sig til Skriften, men efter at have fundet den levende tradition i kirken - med Luthers hjælp måtte han, skønt han var overbevist om i denne sag at have Luther på sin side, spørge, hvorfor Luthers værk var smuldret i de følgende århundreder. Derfor kom han ikke uden om at spørge, om grunden lå hos Luther selv. Lutherbegejstringen, som forblev urokket hele hans liv, blev fra nu af forbundet med en Lutherkritik. Men han var overbevist om, at han også med denne kritik stod Luther nærmere end dem, der lå på maven for reformationen, fordi han just med sin kritik fastholdt og tydeliggjorde, hvad han anså for Luthers intentioner ${ }^{22}$.

I artiklen »Om Kirkehistorien« skriver Grundtvig bl.a.:

"Samler vi nu den christelige Oplysning hos Luther i en Hoved-Sum, da bestaaer den deri, at kun den Helligaand og intet Menneske eller nogen Stand, er Herrens Statholder paa Jorden, at Herrens egne Indstiftelser: Daaben og Nadveren, er de eneste Saligheds Midler hos hans Folk, og udretter kun hvad de kan og skal, naar Ordet paa Guds og Troen paa Menneskets Side i Sandhed mødes og ved Aandens Kraft sammensmelter i Hjertet; men for at det kan skee, maa baade Evangeliet levende og frit forkyndes for alle Folk paa det Maal, de ere $f \phi d t e ~ i$, den hellige Skrift paa Modersmaalet ligge aaben for alle, og de Troende tiltale hinanden med Psalmer og Lovsange og aandelige Viser, ligeledes paa deres Modersmaal, saa der kan leges yndig for Herren i Hjertet $\ll^{23}$.

Helligånden, intet menneske eller nogen stand, er Herrens statholder på jorden. Det vil sige: i kirken har hverken pave, biskop eller præst ret til at udøve formynderskab. Kun Ordet og Ånden skal råde. Grundtvig kan andetsteds prise dette som Luthers opdagelse ${ }^{24}$.Det siger han på baggrund af sin forståelse af kirkehistorien, der forudsætter en beklagelig udvikling, som går tilbage til det 3 . århundrede: i østen vinder med Origenes skriftklogskaben overhånd, medens Tertullians og Cyprians virksomhed fører vestens kirke ind i hierarkiets herredømme, båret af den vildfarelse, at gejstligheden er det 
samme som kirken. Skønt begge dele var forkasteligt, var dog hierarkiet det mindre onde, da dåbspagten forblev urørt. Kirken var ganske vist forstenet, men dog til at genoplive, mens Grundtvigs vurdering af Østkirken er uden formildende træk ${ }^{25}$. Hvis man kender kirkehistorien, siger han, savner man siden Irenæus en præst, der som Luther kun ville vide af Kristus, den korsfæstede, og af ingen anden statholder end Helligånden ${ }^{26}$.

På baggrund af det falske kirkebegreb, Luther mødte, kan man ifølge Grundtvig forstå, at reformatorerne måtte nedbryde det. Det er ligeledes klart, mener han, at en kirkelig afsondring var nødvendig trods fællesskabet om dåbspagten ${ }^{27}$. Kirken var siden Cyprian blevet stadigt værre, så at en reformation, selv over flere århundreder, ville være et Herkulesarbejde, hvorfor det ikke er noget under, at Luther ikke blev færdig. Det var tværtimod et under, at han, udset af forsynet, havde mod til at gå i gang! ${ }^{28}$ Men så er spørgsmålet, på hvilken basis Luther kunne nå til den opdagelse, at kirken ikke er afhængig af gejstligheden. Jo, svarer Grundtvig, efter apostlene var spørgsmålet, hvor Helligånden blev af, og hvordan man fik syndernes forladelse. Gejstligheden havde henvist til sig selv og taget monopol på Helligånden, men intet svar var naturligere end Luthers: hvor Guds Ord, troen og sakramenterne er, dér er kirken - med eller uden embedsstand $^{29}$. Den sidste tilføjelse er interessant, for samtidig bebrejder Grundtvig Luther, at han har ringeagt for embedsstanden. Ikke desto mindre: med denne opdagelse førtes Luther med sit følge lige til den apostolske kirkes hoveddør. Og det var netop, hvad Luther mente med reformation: en tilbagevenden til det oprindelige $^{30}$.

Helligånden som eneste statholder og Herrens indstiftelser som eneste salighedsmidler, så at ordet og troen kan sammensmelte $i$ hjertet: Det er for Grundtvig Luthers anliggende, som han vedblivende holdt fast ved som sit eget. Men det fordrer de ting, som nævntes sidst i citatet: en fri og levende forkyndelse, Bibelen opladt for folket og salmer og åndelige sange, altsammen på modersmålet, med andre ord, alt det, som Luther allerede i verdenskrønikerne prises for. Trods opgivelsen af partiskhed for reformationen, kan Grundtvig ikke komme uden om, at dette er bedre, end det findes andre steder. Ved at henvise - ikke til sin bibelske teologi, men til Ordet, troen og sakramenterne som den kristelige livskilde - gjorde Luther et kæmpeskridt til den apostolske kristendoms fornyelse, hvor- 
ved han kom den så nær som Augustin ${ }^{31}$. Andetsteds fremhæves Luther på Augustins bekostning, når det hedder, at til trods for, at reformatorerne under nedbrydelsen af det falske kirkebegreb måske kom til at skade det sande, er dog Luthers kirkebegreb i katekismerne og i Confessio Augustana himmelsk, selv i forhold til Augustin ${ }^{32}$. Grundtvig mener at kunne vise sine lutherske brødre, at vort lutherske samfund har samme apostolske, urokkelige grundlag som den ældste kirke, renere end bispekirken i England, klarere end pavekirken og langt mere levende end begge, og med større kristelig frihed end noget sted i $1500 \mathrm{år}^{33}$. Alligevel kan han andre steder udtrykke beklagelse over, at kirken ikke rigtigt kommer til orde $\mathrm{i}$ katekismen ${ }^{34}$, og at Luther har talt uforsigtigt om læreembede og om søndagen ${ }^{35}$. Dog er den sidste bemærkning, om læreembede og søndag, fra 1830, da Grundtvig stadig havde helt ulutherske tanker om bispeembedet, som han siden fortrø $\mathrm{d}^{36}$.

Luther holdt sig altså til dåben, nadveren og evangeliet som kirkens kendetegn, og i overensstemmelse hermed gjorde han trosbekendelsen, sakramentordene og Herrens bøn til børnelærdom. Af Luthers katekisme, hævder Grundtvig, lærte folket bedre end i 1.000 år at skelne det grundkristelige fra mennesketant. Skønt det gik galt i det 17. århundrede - med ortodoksien - var dog ægte lutherskhed nærmere apostolsk kristendom end noget siden Augustin, skønt man stod med ét ben $\mathrm{i}$ den apostolske kirke, og det andet $\mathrm{i}$ den alexandrinske skolemestertankegang. Det var ganske vist misligt, men efter pavedømmet var også et halvt himmerige en stor ting ${ }^{37}$.

Med hensyn til reformationen bevarer Luther derfor sin særstilling for Grundtvig. Kun i den lutherske reformation, siger han, bevares den grundsætning, at det, der væsentligt udgør trossamfundet, skal bevares uforandret ${ }^{38}$. Luther var den eneste, der reformerede i Kristi ånd. Hans reformatoriske grundsætning er uforbederlig: Kristi indstiftelser, Guds Ord og Guds Ånd ${ }^{39}$, og det er hans udødelige fortjeneste at have muliggjort en fri og levende forkyndelse, Skriftens tilgængelighed for alle og åndelige sange, altsammen på modersmålet. Derfor kan da også den fuldt afklarede Grundtvig betone, at han holder fast ved Luther og hans reformation, ved hans salmer og hans katekismer. Til sine lutherske medkristne kan han sige, at de, der ikke er indforstået hermed, ikke skal regne med at kunne lære noget af ham ${ }^{40}$. I samme skrift (»Kirkelige Oplysninger«) gennemgår han kirkeartiklen i Den augsburgske Bekendelse, som han tolker helt på 
linie med sin egen kirkeforståelse, så at han kan hævde at have et ægte luthersk kirkebegreb. Det vil sige: en tvangfri kirke, der er fjernt fra enhver ide om, at der skulle findes flere kirker ${ }^{41}$.

Som det skulle fremgå af denne fremstilling, vedbliver Grundtvig, for så vidt angår det, han kalder det "grundkristelige «, dvs. det, som angår enhver kristen i lige grad, at se op til Luther. Men, som allerede antydet, har han også alvorlige indvendinger. Ved at sammenblande sine fundamentale indsigter med skriftprincippet, bliver Luther for Grundtvig medskyldig i de dystre konsekvenser, der nu er synlige i den rationalistiske teologi ${ }^{42}$. Luthers tro, som er det uforanderlige, der skal fastholdes, kan man nu kun være tro imod ved at afvise den lutherske teologiske metode.

Som han selv siger, taler Grundtvig her af egen erfaring som den, der selv havde forvekslet Bibelen med kristendommen ${ }^{43}$. Luther pr $\varnothing-$ ver han at undskylde. Han kan i samme skrift opregne Luthers fejl i denne forbindelse og samtidig skrive, at Luthers skriftfortolkning stemmer med troens og indstiftelsens ord, og at han aldrig afveg et hårsbred herfra ${ }^{44}$. Han kan hævde, at det, Luther egentlig mente, var, at hvis nogen ville råde over troen - som Middelalderen og pavedømmet - var de skyldige at føre skriftbevis for deres krav, og samtidig kan han sige, at Luther lod sig forlede til påstande, der nu bruges til at bestride kirketroen ved hjælp af kirkebogen ${ }^{45}$. Luther byggede på grundvolden, men forvildes ofte i sine stridsskrifter af den nye videnskabelighed, som han havde sluttet forbund med mod overtro og vankundighed ${ }^{46}$. Luther burde have vidst, at Bibelen ikke er beregnet til at stå på, men til at ligge opslået på alteret ${ }^{47}$.

Når Grundtvigs udsagn om Luther som teolog kan synes ikke at være helt konsistente, for ikke at sige selvmodsigende, har det en forklaring. Han mente, at Luther med skriftprincippet havde et galt grundlag, men at han personligt ved sin profetiske forkyndelse undgik de farer, princippet siden skulle vise sig at rumme. Derfor kan han sige: vi skal følge Luther, men af andre grunde end dem, han an$\operatorname{gav}^{48}$. Det tjener også til en vis grad som undskyldning for Luther, at hans fejl ingenlunde var ny i kirken: den går tilbage til den alexandrinske skolemester-tankegang, der altså desværre blev genoptaget af protestanterne ${ }^{49}$. Luther havde derfor uret i teorien, men ret i sin praksis. I hans tilfælde forblev de forkerte principper uskadelige, men ved at opstille dem blev han medårsag til lutherdommens fordærv. De skriftkloge overtog magten i kirken med ny skolastik og 
umyndiggjorde folket. Det eneste lyspunkt, Grundtvig kan få øje på, er, at katekismen og salmerne ved gudstjenesten fastholdt kirkens trosvidnesbyrd trods al teologisk vilkårlighed. Men Grundtvig kan ikke fritage Luther fra ansvaret for at have givet »skolen«, dvs. den teologiske videnskabelighed, en ledende rolle i kirken, som overhovedet ikke tilkommer den. Modsætningen hos Grundtvig mellem Skriften og Guds levende, nærværende Ord har selvfølgelig væsentlig betydning i denne sammenhæng. Luther havde efter hans mening ikke noget klart begreb om forskellen mellem Guds levende ord, Den hellige Skrift og teologernes prædiken ${ }^{50}$. Det fik ingen skadelige virkninger hos ham selv, men det var skæbnessvangert for eftertiden.

Hvordan kunne det gå sådan? Ja, Grundtvig finder noget af forklaringen $\mathrm{i}$ et misforhold mellem Luthers inderste $\emptyset$ nsker og hans personlige baggrund. Han ville sætte enfoldige kristne i frihed, men han var en munk, der på grund af sine egne erfaringer ikke forstod, at hans omgang med Skriften umuligt kunne blive hvermands sag ${ }^{51}$. Med andre ord: han anså sine egne, i grunden højst specielle forudsætninger for at være almengyldige. Han satte først, hvad han burde have sat sidst, nemlig den skriftkloges individualitet. Han vakte den slumrende menighed med sin profetiske skriftfortolkning, men forstod ikke, at denne hverken lod sig systematisere eller efterligne. Resultatet blev et åndeligt skyggerige, hvori solen skinnede, men hvor der ikke fandtes varme. Grundtvig søger her at indkredse den individualisme, som for ham var en nødvendig følge af skriftprincippet. Skriftfortolkningen er med nødvendighed individuel - enhver læser, som han har forstand til - og derfor også diskutabel og hverken til at leve eller $\mathrm{d} \varnothing$ på - til forskel fra Guds levende Ord, der er overleveret fra slægt til slægt fra apostlenes dage.

Man mene nu, hvad man vil, om denne forklaring. Grundtvig har naturligvis ret $\mathrm{i}$, at der ikke kan bygges kirke - heller ikke et lille bedehus i den hellige almindelige kirke, som Grundtvig et sted kalder den lutherske kirke ${ }^{52}$ - på personlige erfaringer, det være sig Luthers eller andres. At gøre Luthers oplevelser til paradigme for reformationen var ikke ukendt i det 18. og 19. århundrede. At Grundtvig afviser ideen, er der ikke noget at sige til. Det var ikke i skolen, men i kirken, han så Luthers meget store og uforgængelige indsats. Over for Luthers teologi i bredere forstand var han mere forbeholden. Luthers bibelske teologi, skriver han i Verdenshistorien, er langtfra så beundringsværdig som hans kristne Tro, kirkelige Takt, Seerblik, hel- 
temodige Kamp, folkelige Tone og mesterlige Stil ${ }^{53}$. Det er ikke småting, der bliver tilbage efter kritikken.

Og dog er de dystre toner aldrig langt borte. Det gik godt, så længe Skriften - hos Luther selv - blev udlagt »med Aandens Lys og Troens Liv«, men, siger Grundtvig, »lægger man Bogstaverne sammen, uden Aandens Liv og Troens Lys, tjener det kun til at skabe en sovende Menighed, et Tjørne-Gærde af Spidsfindigheder, et Iisbjerg af Dogmatiker og en Syndflod af Postiller « ${ }^{54}$. På denne baggrund kan Grundtvig endog betegne Luthers historie som tragisk ${ }^{55}$. Det lykkedes ham ganske vist at befri menigheden fra pavedømmet, men den blev snart ført tilbage til fangenskabet af verdslig magt og ny skolastik $^{56}$. Grundtvig er meget ivrig efter at fritage Luther for ethvert ansvar for fyrsternes overtagelse af magten i kirken, som han mener skyldes et samarbejde mellem fyrsterne og lutherske teologer, der ville binde folkene til deres symbolske bøger, hvad også fyrsterne havde en interesse $i^{57}$. Jeg vil lade mig nøje med disse få ord vedrørende kirketvangen, som jo hele tiden beskæftiger Grundtvig. Det gør jeg for at få tid til noget andet, som jeg finder meget vigtigt.

Så længe Grundtvig var forkæmper for en kristen kultur, var det ligetil, at han måtte interessere sig for reformationens og lutherdommens folkelige og borgerlige betydning. Men det er i ikke mindre grad, om end med en anden begrundelse, tilfældet efter 1825 - og, om man vil, efter 1832. I Verdenshistorien konstaterer Grundtvig, at kristendommen fandtes før Luther. Derfor må man forklare sig hans reformation ud fra den kristne tros og kirkes historie i en levende sammenhæng med folkenes forrige og følgende levnets$1 \varnothing b^{58}$. Da åndsfrihed og folkelighed er betingelserne for, at kristendommen kan vinde fodfæste, er det, trods adskillelsen mellem kristendom og menneskelighed, afgørende, at der findes en folkelig sammenhæng. Er den ikke til stede, må kristendommen selv skabe den $^{59}$. Det er derfor meget vigtigt at anskue reformationen i dette lys.

Derfor må reformationen ses i forbindelse med det, Grundtvig kalder den nye kristenhed. Hvis ikke den skal være rent hekseri for os, må den have sin grund dybt inde i middelalderen: "Man maa enten takke Historien for Alt, eller erklære den aaben Fejde « ${ }^{60}$. Grundtvig går tilbage til Gregor den Stores udsendelse af benediktinere til England, hvorved, om man så må sige, lysestagen flyttes fra oldtidens gamle folk til de nye, englænderne og gennem dem til ty- 
skerne og videre til nordboerne. Set $\mathrm{i}$ dette lys siger Grundtvig, at den tyske reformation ikke var nogen egentlig fornyelse af oldkirken eller vort gamle folkeliv, men en sejrrig kamp for det altsammen: for kristenlivet, folkelivet og oplysningen og et åndeligt Hermannsslag, der viste romerne, hvor grænsen gik, med tilbagevisning af romerskhed, papisteri og latin ${ }^{61}$. Sætter man pris på folkelighed og modersmål, mener Grundtvig, må det være en hovedsag at indse den lutherske reformations verdenshistoriske betydning ${ }^{62}$.

Hvad reformationen havde sat i gang, blev bremset i det 17. århundrede, da man pinte livet af alt det, der var født i det 16., for slet ikke at tale om det 18. århundrede, der helt opgav både kristendom og folkeliv ${ }^{63}$. Alligevel var det ikke forgæves. Bibelen på modersmålet og bibelsk prædiken har mere, end nogen vidste, forberedt almueoplysning og menneskelig dannelse. Fortroligheden med de bibelske historier har givet forstand på livet. Det var kristeligt en fejl at gøre Bibelen til kristelig trosregel, men selv i dette fejlgreb kan Grundtvig finde noget godt: ved at fremme oplysningen har det frelst vort borgerlige selskab ${ }^{64}$.

Således er altså tilbagegangen efter Luthers død trods alt ikke den rene elendighed. Der er stadig tydelige spor af den lille hytte inden for den almindelige kirke, som kaldes den »lutherske«, med hjertelig tale og sang og dejlige bibelske historier. I 200 år var dansk og tysk forsonet med Luthers katekisme, Bibel og salmebog, så man dårligt kunne mærke, om det foregik på det ene eller det andet sprog ${ }^{65}$. Det er en konstatering, der både angiver, at det grundkristelige overlevede, og samtidig, at folkeligheden lå i dvale. Men Luther bar en ny verden i sig, der med tiden måtte udvide sig til alt menneskeligt ${ }^{66}$. Med tiden, mener Grundtvig, vil beundringen for Luthers dybe blik vokse ${ }^{67}$.

Den ufærdige reformation vil derfor nu komme et stykke videre, skønt fuldendelsen må vente til tidernes afslutning. Afskaffelsen af den tvang, hvormed efterfølgerne standsede Luthers værk, er ved at nærme sig enden, og reformationens vældige kraft i forhold til folkelighed og modersmål gør sig gældende som aldrig før ${ }^{68}$. I $\gg$ Christenhedens Syvstjerne «, der priser Luthers dåd, finder vi også den måske hårdeste vurdering af Luther, når Grundtvig sammenligner ham med Moses, der kun måtte se, men ikke betræde, det forjættede land, et billede, som Luther forøvrigt brugte om Erasmus af Rotterdam ${ }^{69}$. Det grundkristelige hos Luther skal fastholdes og videref $\varnothing$ res, men 
hans fejltagelser skal afskaffes og hans værk føres nærmere fuldendelsen, hvor hans kræfter ikke slog til, eller hvor han ikke så klart nok. I forordet til Søndagsbogen nævner Grundtvig det uacceptable alternativ, som det gælder om at undvige: enten at spærres inde $\mathrm{i}$ en gammel lærebygning med forstenet sprog eller at rive sig løs fra trosregel og kirkesprog, de to ting, der aldrig forældes. I stedet for gælder det om at have et klart blik for skellet mellem det uforanderlige og det fremskridende. De to ting svarer til Kristustroen, der karakteriseres ved fasthed, og Helligånden, der er frihedens ånd ${ }^{70}$. Man kunne med Grundtvig også sige: troen er den samme til alle tider, men teologien er bestemt af tid og lejlighed. Måske kunne man sige, at Grundtvig dermed præciserer sin holdning til den kristne overlevering, som er teologiens eneste genstand. Sagen er altid den samme, men udtrykket - eller med Grundtvig: den kristelige oplysning - er undergivet historisk forandring. Indser man ikke det, men bliver man stædigt $i$ en svunden tid, er det selve sagen, man svigter. Livet er det samme, men lyset er historisk bestemt.

Jeg skal undlade en egentlig opsummering af, hvad jeg har sagt. Efter min mening er Grundtvigs måde at forholde sig til Luther på uden sidestykke $\mathrm{i}$ hans tid. Luther var genstand for de forskelligste vurderinger i det 19. århundrede, fra næsegrus beundring for frihedshelten, troens ensomme kæmpe, som nogle mente, eller for hans lære, som nylutherdommen ville genskabe, og lige til ligegyldighed eller afvisning. Men ingen andre end Grundtvig forenede forherligelse med kritik i den overbevisning just dermed at stå reformatoren nærmere end alle hans ukritiske beundrere.

Lad mig slutte med et citat fra en af de taler om Luther, Grundtvig holdt i Vartov på reformatorens fødselsdag:

»Ja, mine Venner, jeg er ingenlunde af dem, der mene, at vi skal staa stille ved hvad Morten Luther gjorde for 300 Aar siden; thi kun Døden staaer stille, Livet er altid i Bevægelse. Jeg arbejder nu og min Fader arbejder, siger Vorherre Jesus, alle Dage til det sidste, og det samme maa alle hans Tjenere og alle Guds Børn sige. Der skete ingenlunde i Luthers Dage alt hvad der kan og bør skee for Evangeliets fri og levende Virksomhed for Menneske-Hjertet, for Kvinder og Børn, og meget af hvad der skete gik snart igjen forloren, fordi man vilde staa stille, vilde ikke gaa frem, og maatte derfor gaa tilbage, da 
Livet aldrig kan staa stille. Men jeg vil ikke staa stille ved nogen Grav, ikke selv ved Herrens, og mange siger derfor om mig, at jeg er ingen ægte Lutheraner, og der er kun tre Navne jeg vil trættes om, det er: Menneske, Kristen og Dannemand; men jeg vil dog ingen vige i kjærlig Amindelse af Morten Luther, i Taksigelse til Gud for ham som den ypperligste Fader i Kristus siden Apostlenes Dage ... $\ll^{71}$.

\section{Noter}

1 Foredrag ved Grundtvig-Selskabets 50 års jubilæumskonference i Køge, august 1997. Da foredraget trykkes, som det blev holdt på symposiet $\mathrm{i}$ Køge, har jeg valgt at lade disse bemærkninger stå. Jeg skal dog ikke undlade at henvise til det værk, som siden er udkommet: Gerald M. Haslam, N.F.S. Grundtvigs faedrenearv (1783-1815), Århus 1998.

2 N.F.S. Grundtvig, Dag- og Udtogsbøger ved Gustav Albeck, København 1979, I, 46.

3 Smst., 17-18.

4 Smst.,

5 Holger Begtrup, Udvalgte Skrifter 2, 48, »Til min Fader« strofe 4:

Jubellærer! paa din Jubelfest

Se, hvor Man Lutheri Lig omfører!

Han var Herrens ypperlige Præst,

Men hans Aand i Liget ei sig rører:

Navnet har han, som fra Herren lød,

At han lever, skøndt han dog er død.

Se, hvor de paa Mindestenen hugge!

Den skal reises paa hans Jubelfest,

Med den vil de Graven da tillukke,

Frit bekende: død er Herrens præst.

Georg Christensen og Hal Koch, Varker i Udvalg 7,

166-172, »Frants Volkmar Reinhards Minde«.

6 Manuskriptet er udgivet af William Michelsen, se Grundtvig-Studier 1956, 64-75. 
7 US 10, 341 (Kirke-Spejl).

8 Grundtvig-Studier 1956, s. 73: Vi kunne ikke nægte det, at Luther selv vel gik meget for vidt i sin Lære om de gode Gerninger ---.

9 Som anm. 7.

10 US 2, 251.

11 US 1, 141.

12 US 2, 256: "De ægte Lutheraner vare saa godt som muligt forvarede baade mod farlig Grublen og Sværmeri; thi --- de have i det skrevne Ord en ubedragelig Prøvesteen ---«.

13 US 2, 292-293.

14 Udsigt over Verdens-Krøniken fornemmelig $i$ det lutherske Tidsrum, København 1817, 387.

15 US 4, 667 (Om Christendommens Sandhed).

16 Verdenskrønike 1817, 387; 393.

17 Smst. 146-149. Jfr. US 2, 254f. (Verdenskrønike 1812).

18 US $1,169$.

19 Se Christian Thodberg, „Var Grundtvigs Nadversyn luthersk?«, Grundtvig-Studier 1975, 7-32.

20 US 5, anmærkning på s. 316.

${ }^{21}$ US 5, 166.

${ }^{22}$ US 5, 326f. (Skal den lutherske Reformation virkelig fortsattes).

${ }^{23}$ US 9, 73f.

${ }^{24}$ US 7, 551 (Haandbog $i$ Verdens-Historien III, 1843).

${ }^{25}$ US 7, 547-548 (smst.). 
26

27

28

29

30 US 5, 285 (Skal den lutherske Reformation virkelig fortsattes).

31 US 7, 544 (Verdenshistorie III).

32 US 8, 384 (Kirkelige Oplysninger).

33 US 8, 375 (smst.).

34 US 7, 552 (Verdenshistorie III).

35 US 5, 346 (Skal den lutherske Reformation virkelig fortsattes).

36 Jfr. Grundtvigs Forord til 1863-udgaven af »Skal den lutherske Reformation virkelig fortsættes?«, US 5, 355.

37 US 7, 552f. (Verdenshistorie III).

38 US 5, 282 (Skal den lutherske Reformation virkelig fortsattes).

39 US 8, 374 (Kirkelige Oplysninger).

40 Smst.

41 US 8, 386-390 (smst.).

42 Se Lutherkritikken i 3. del af »Skal den lutherske Reformation virkelig fortsættes«, US 5, 318-355.

43 Se fx US 4, 520-523 (Om Christendommens Sandhed)

44 US 5, 335 (Skal den lutherske Reformation virkelig fortsattes).

45

46

US 5, 325 (smst.). 
47 US 4, 547 (Om Christendommens Sandhed).

48 US 8, 374 (Kirkelige Oplysninger).

49 US 5, 324f. (Skal den lutherske Reformation virkelig fortsattes).

50 US 9, 92 (Om Folkeligheden og Dr. Rudelbach, 1848).

51 US 4, 582f. (Om Christendommens Sandhed); jfr. US 5, 348f. (Skal den lutherske Reformation virkelig fortsattes).

52 US 7, 541 (Verdenshistorie III).

53 US 7, 544.

54 US 4, 547 (Om Christendommens Sandhed).

55 US 4, 660 (smst.)

56 Om den protestantiske skolastik, se allerede Verdenskrønike 1817, $393 \mathrm{f}$. US 4, 659 (Om Christendommens Sandhed); US 5, 348 (Skal den lutherske Reformation virkelig fortsattes).

57 US 7, 571f. (Verdenshistorie III); US 8, 385f. (Kirkelige Oplysninger osv.).

58 US 7, 533 (smst.)

59 US 9, 85 (Christendom og Folkelighed)

60 US 7, 535 (Verdenshistorie III).

${ }^{61}$ US 7, 538 (smst.).

62 US 7, 533 (smst.)

${ }^{63}$ US 7, 539 (smst.).

64 US 7, 566-568 (smst.).

65 US 7, 541 (smst.).

66 US 7, 542 (smst.). 
${ }^{67}$ US 7, 554 (smst.).

${ }^{68}$ Se 2. del af »Skal den lutherske Reformation virkelig fortsættes?«.

69 Christenhedens Syvstjerne, udgivet af Th. Balslev, København 1955, 150151 (5. del, strofe 24-27).

70 US 5, 187 (Christelige Pradikener eller Sфndags-Bog).

71 Kirkelige Lejlighedstaler af N.F.S. Grundtvig, udgivet af C.J. Brandt, København $1877,471 \mathrm{f}$. 